\title{
Being, Knowledge, and Nature in Novalis
}

\author{
A L ISON STONE*
}

\section{N T R O D U C T I O N}

IT IS NOW WIDELY RECOGNIZED that Early German Romanticism makes important contributions in epistemology, metaphysics, ethics, and aesthetics, but there is considerable disagreement on what its central philosophical positions are. According to one of its most influential interpreters, Manfred Frank, the German Romantics believe that the unity of being underlies finite phenomena, and that we can only strive towards, and never achieve, knowledge of being. ${ }^{\mathrm{I}}$ In contrast, another leading interpreter, Frederick Beiser, argues that for the Romantics the unitary reality underlying finite phenomena can be known because it is a self-realizing organic whole which develops in an intelligible way. ${ }^{2}$ Here I want to provide support for a third interpretation of Early German Romanticism through a reading of the writings on nature of Novalis (Friedrich von Hardenberg). I shall argue that, from I 795 to I 800 , Novalis advances from believing in unknowable being to believing that we can know reality, ultimately, to be self-organizing nature, but that, because nature organizes itself spontaneously, we cannot understand or explain why it assumes the particular forms of organization that it does. Thus, on Novalis's mature view, nature is partly intelligible, insofar as it develops organically, but partly unintelligible, insofar as it develops spontaneously. The evolution in Novalis's thinking becomes apparent once we appreciate that he has a central aim of showing how we could reacquire a (presently lost) experience of natural phenomena as "enchanted"-meaningful, mysterious, and animated by spirit. ${ }^{3}$ As

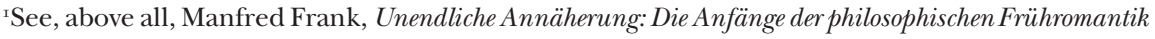
[Unendliche Annäherung] (Frankfurt: Suhrkamp, I997).

${ }^{2}$ Frederick Beiser, German Idealism: The Struggle Against Subjectivism I 78 I -I 80 I [German Idealism] (Cambridge, MA: Harvard University Press, 2002), 349-46I; The Romantic Imperative [Romantic Imperative] (Cambridge, MA: Harvard University Press, 2004).

${ }^{3}$ As Dennis Mahoney (The Critical Fortunes of a Romantic Novel: Novalis's Heinrich von Ofterdingen [Columbia: Camden House, I994], I25) says, "the chief characteristic of Novalis's work [is] the attempt to counteract the demystified character of the modern, technical world."

\footnotetext{
* Alison Stone is Senior Lecturer in Philosophy at the University of Lancaster.
}

Journal of the History of Philosophy, vol. 46, no. I (2008) I 4 I-64

[I4I] 
it transpires, Novalis can satisfactorily explain how we could overcome our presently "disenchanted" view of natural things only by arguing that all these things correspond meaningfully with one another-correspondences which, he then explains, manifest the spontaneous self-organization of nature as a whole.

The change in how Novalis thinks of being and nature is not only of historical interest, but also bears on the question of whether, and how, we should revalue the natural world. Arguably, modern western conceptions of nature implicitly devalue it, and therefore result in environmentally damaging practices. ${ }^{4}$ Perhaps, then, we should revalue natural things by recognizing that they display agency, creativity, and rational intelligibility-qualities traditionally seen as sources of value in humans. Yet this approach seems to assume that natural things can have value only insofar as they resemble or approximate to humans. So perhaps, instead, we should revalue natural things by recognizing that they are unintelligibly different from us, and merit wonder and respect on that account. However, on its own, the principle that we should respect the unintelligibility of nature seems too thin to provide everything that is required for renewed ethical appreciation of nature. This appreciation must consist in something more complex: a combination of the perception that nature is wondrously unintelligible with a perception that, in other respects, it exercises creativity and rationality of a recognizable kind. Novalis's mature thought provides a way to combine these perspectives, I hope to show.

The argument of this paper is structured as follows. Section I offers an initial account and evaluation of Frank's and Beiser's interpretations of Romanticism. This is necessary because a plausible reading of any Romantic thinker must build on these interpretations, while also identifying and correcting their limitations. Moreover, because these interpretations illuminate the philosophical significance of Early German Romanticism (namely, its intervention into post-Kantian debates about knowledge and being, self and nature), assessing these interpretations provides a way in to reading Romanticism-and, specifically, Novalis's reflections on nature-philosophically. With this entry-point established, section 2 re-examines Novalis's account of the unknowability of being in his Fichte-Studies (I795-96). As I explain, this account underpins his subsequent idea that romantic poetry can "re-enchant" natural phenomena by portraying them as referring, meaningfully, to unknowable being (in this context, I explain how Novalis understands "disenchantment" and "re-enchantment"). ${ }^{5}$ Section 3 identifies a problem in Novalis's account of re-enchantment: this account presupposes that we originally experience natural phenomena as meaningless, purely material, items (prior to re-imagining them poetically), which implies that the "disenchanted" view of nature can never be

\footnotetext{
${ }^{4}$ See Carolyn Merchant, The Death of Nature: Women, Ecology, and the Scientific Revolution (London: Wildwood House, I982).

${ }^{5}$ Saying that Novalis opposes disenchantment (Entzauberung) might sound anachronistic, but the concept, if not the term, is present in his thought, I will argue. The antithetical term 'Bezauberung' is present. See, for example, Novalis, Schriften, ed. Richard Samuel (Stuttgart: Kohlhammer, I960-), II, 60I, \#355; Novalis, Philosophical Writings, trans. and ed. Margaret Mahony Stoljar (Albany, NY: SUNY Press, I997), 27. Here and subsequently, references to Novalis's Schriften are to volume, page, and, when applicable, fragment number. References are also given to corresponding pages in English translations when available. I quote from these translations-but sometimes modify them without special notice-whenever possible.
} 
wholly superseded. Consequently, in section 4 I argue that in his Allgemeine Brouillon (General Outline, I798-99) Novalis adopts the new view that natural things are in themselves meaningful and inspirited, and that, in the right culture, we could all directly observe and experience these qualities in natural things. Section 5 clarifies Novalis's emergent view that we can know nature as a whole to be spontaneously self-organizing, but that, because nature's development is spontaneous, we can never wholly comprehend it.

This reconstruction of the intellectual trajectory of Novalis cannot suffice to justify the more general claim that the Early German Romantics moved away from belief in unknowable being toward the belief that infinite, "absolute," reality can be known to be spontaneously creative nature (which, in its spontaneity, nonetheless eludes full comprehension). ${ }^{6}$ But, since Novalis is the most overtly philosophical Romantic, and the most closely engaged with epistemological and metaphysical questions, my reading of him does significantly increase the plausibility of such an interpretation of Romanticism-an interpretation which reconciles Beiser's and Frank's emphases on the knowability and unknowability of the absolute.

\section{IN TER P RETING EA RLY GERMA N ROMA N TICIS M}

The dispute between Beiser and Frank concerns whether the Romantics believe (as Frank claims) that the absolute is the unknowable unity of being, or whether they believe (as Beiser claims) that the absolute is the organic and rationally intelligible unity of nature. Let us first examine Frank's interpretation. He argues that the Romantics endorse (I) ontological realism, "the thesis that reality exists independently of our consciousness," and (2) epistemological realism, "the thesis that we do not possess adequate knowledge of reality." Frank goes on to say that,

\footnotetext{
${ }^{6}$ Novalis's transition to the latter belief is not clear-cut; his earlier writings sometimes anticipate his later organicism, while the later writings regularly reiterate or re-examine preceding themes. Nonetheless, certain tendencies dominate at each phase of Novalis's thought, and these are my focus here.

${ }^{7}$ Manfred Frank, The Philosophical Foundations of Early German Romanticism [Philosophical Foundations], trans. Elizabeth Millán-Zaibert (Albany, NY: SUNY Press, 2004), 28. (This is a translation not of all of Unendliche Annäherung, but of a manuscript that later became the third part of that book.) Frank states that "ontological" and "epistemological" realism together make up Romantic "realism" (PhilosophicalFoundations, 28). He understands Romantic realism in opposition to "idealism," which he takes to be the view that reality depends on our minds, such that we can know it exhaustively (Unendliche Annäherung, 27). Some would object to Frank's definition of 'epistemological realism', which, by contrast, Kenneth Westphal, for example, defines as the view that "there is a way the world is which does not depend on our cognitive or linguistic activity; and ... we can know the way the world is" (Westphal, Hegel's Epistemological Realism [Dordrecht: Kluwer, I989], 3; emphasis added). Frank's definition is also a potential source of confusion because Beiser describes his quite different interpretation of Romanticism as "realist" too. For Beiser, though, Romanticism is both realist and idealist: realist in holding that reality exists mind-independently, idealist in holding that reality is independently rational (and so can be known). Thus, Beiser admits the possibility of "objective" idealism (Beiser, German Idealism, I I-I3) - a position that he ascribes to the Romantics—whereas Frank restricts "idealism" to the thesis that reality is mind-dependent. Since the divergences between Frank's and Beiser's understandings of 'idealism' and 'realism' threaten to obscure rather than illuminate their substantive disagreements, I will generally avoid these labels; as Fred Rush notes, "tagging things 'realist,' 'idealist,' 'anti-realist,' etc. is [n] ever very helpful" (Rush, review of Foundations, by Manfred Frank, Notre Dame Philosophical Reviews, http://ndpr.nd.edu/review.cfm?id=I024). Moreover, any application of these labels within a discussion of Novalis would raise the question of how Novalis understands "idealism" and "realism," but although he refers to these positions and proposes to synthesize them (Novalis, Schriften, III, 384 , \#634; Philosophical Writings, I3 I), he never explains in what he takes them to consist.
} 
in endorsing these positions, the Romantics remained faithful to Kant. ${ }^{8}$ We might conclude that Frank thinks that the Romantics believe that we cannot know about things as they are in themselves, independently of how they appear to us given our mode of representation. However, Frank claims, the Romantics characterize the independent reality that they affirm not simply as things in themselves but as "the ground of unity of physical and mental reality." The Romantics, Frank contends, are monists for whom one unitary substance precedes the distinctions between the mental and the physical, and, correspondingly, between subjects and objects. ${ }^{10}$ Why, then, can we not attain knowledge about this unitary substance? For the Romantics, all knowing involves conceptual discrimination, and so we cannot cognitively apprehend that which is wholly devoid of distinctions. As Frank shows, Novalis defends this view of knowledge in his Fichte-Studies. Novalis argues that all knowledge and consciousness involve conceptualization and that "all conceptualization is determination, involving some form of negation where one predicate is contrasted against another." ${ }^{\text {II }}$ Consciousness distinguishes objects from one another and (implicitly) distinguishes the self, as subject of consciousness, from these manifold objects. Consequently, we can only know about or have consciousness of finite entities, ones that we conceptualize in their difference from other such entities.

As Frank notes, a question arises here. If the Romantics deny that we can know about unitary being, then how can they legitimately claim that unitary being exists and is, specifically, unitary? Or, as Frank puts it, since the Romantics' account of knowledge means that "we [do not] possess the possibility of securing this [monistic] ontological presupposition through cognitive means," how is Romantic monism defensible? ${ }^{\mathrm{I2}}$ Romantic monism would be defensible if it were supported by some kind of apprehension of reality as a unity, where this kind of apprehension lacks the status of knowledge. Accordingly, Frank argues, the Romantics hold that we sense or feel unitary being but do not thereby know about it. The Romantics, including Novalis, believe that feeling (Gefühl), whereby things are given to us or sensed by us, forms a component in all experience. ${ }^{\mathrm{I}}{ }^{3}$ Since everything that we feel has this character of being given, givenness constitutes a general character which pervades all of these felt things. This single, all-pervasive, character is the unitary being of these things. ${ }^{14}$ On every occasion of feeling, we are aware that something is given

${ }^{8}$ Frank, Philosophical Foundations, 29.

${ }^{9}$ Frank, Unendliche Annäherung, 27.

${ }^{10}$ Frank, therefore, also characterizes Romanticism as "a combination of ontological monism and epistemological realism” (Frank, Philosophical Foundations, 56).

${ }^{11}$ Beiser, German Idealism, 372.

${ }^{12}$ Frank, Philosophical Foundations, 56.

${ }^{13}$ Novalis, Schriften, II, I I 5 , \# I 7; Novalis, Fichte Studies, ed. Jane Kneller (Cambridge: Cambridge University Press, 2003), I4.

${ }^{14}$ According to Frank, the Romantics advance various versions of this argument, all descending from arguments made by Jacobi in the second ( 1789 ) edition of his Spinoza Letters. Jacobi's argument presupposes his reading of Kant on judgments of being (Kant discusses these when criticizing the ontological argument for the existence of God). As Jacobi reads Kant, predicative judgments "posit" their predicates relatively, in relation to their subjects, whereas judgments of existence "posit" their subjects absolutely, without relation to anything else. We can only legitimately posit something absolutely if it is given to us in sense-experience. Now, for Jacobi, this 'absolute'/'relative' distinction 
and, indirectly, are aware of its givenness or being. Here we do not comprehend being through predicative judgments, but simply apprehend being, through our feeling, as non-finite and unitary.

Confirming Frank's interpretation, Novalis in the Fichte-Studies maintains that, although we cannot know about being, we do have a feeling of it, ${ }^{\mathrm{I} 5}$ and this motivates us to try to grasp being cognitively. But, Novalis writes, we can cognitively access being only in the "illusory" form of a plurality of distinct objects. ${ }^{16}$ Any attempt to cognitively grasp being results merely in the acquisition of another item of finite, predicative knowledge. Novalis argues, though, that reflection can make us aware that our knowledge of finite entities does not amount to knowledge of being. This recognition compels us into fresh attempts to know being-attempts which inevitably fail and must endlessly be repeated. Novalis concludes that we must acknowledge that our intellectual endeavors, including philosophy, are implicated in what he calls this "unending activity" of striving to know being. ${ }^{17}$

Novalis's idea of "unending activity" is bound up with what Frank characterizes as his anti-foundationalist epistemology. Indeed, Frank avers that the Romantics generally endorse anti-foundationalism, namely the view that there are no certain principles from which the rest of our knowledge can be derived. ${ }^{18}$ For the Romantics, any knowledge-claims which form the starting-point of a philosophy can only be tentative and corrigible, liable to refutation or amendment in light of subsequent arguments and discoveries. The justification for a belief, therefore, increases in proportion as it coheres with all of the other beliefs we have formed. Nonetheless, the Romantics deny that we can ascend to certain knowledge through a process of systematically correcting our errors. Although we endlessly strive to integrate our beliefs, these can never be definitively systematized due to our constant acquisition of new beliefs, which impact upon the entire fabric. For example, in Novalis's version of this anti-foundationalist position, we cannot cease striving to know being, but this striving generates endless new finite judgments, each of which must be integrated into our existing body of judgments.

Novalis takes being, or unitary substance, to precondition not only the subject/object distinction, but also the subject's consciousness of itself, as Frank shows

implies that the absolute kind of positing is basic, because it is just positing simpliciter, without the additional establishing of a relation (Frank, Philosophical Foundations, 6I-62). Jacobi infers that the basic sense of 'is' is existential, and that whatever is, is in the same basic sense, namely, it is given to our senses. From this, he reasons that the character of givenness which pervades all sensible things is their (unitary) being (Frank, Philosophical Foundations, 69-7I; Jacobi, "Concerning the Doctrine of Spinoza in Letters to Herr Moses Mendelssohn," in The Main Philosophical Writings and the Novel Allwill, trans. George di Giovanni [Montreal: McGill-Queen's University Press, I994], I94). Jacobi’s argument has problems; can he legitimately move from the claim that there is one basic sense of 'is' to the claim that being is one single phenomenon? Nonetheless, he opens up a line of thinking which is decisive for the Romantics.

${ }^{15}$ On feeling as the starting-point for intellectual endeavors, see Novalis, Schriften, II, II4-I 8, \# I 5-\# I 9; Fichte Studies, I 3-I6. On the connection of feeling with being, see Schriften, II, 266-68, \#556; Fichte Studies, I 65-66.

${ }^{16}$ Schriften, II, I79-80, \#234; Fichte Studies, 77-78.

${ }^{17}$ Schriften, II, 270, \#566; Fichte Studies, I67.

${ }^{18}$ For this definition, see Frank, Philosophical Foundations, 30. Here, Frank calls "foundationalist" those "philosophies that start from the certainty of a highest and immediately evident fundamental proposition from which our valid beliefs can be derived as logical implications." 
with reference to the Fichte-Studies. On Frank's reading, Novalis criticizes Fichte's idea that we each have immediate self-consciousness: an immediate apprehension of the unity of the self, preceding reflective self-consciousness. Novalis accepts that we have this immediate self-acquaintance, but he denies that it constitutes a form of self-consciousness. Self-consciousness is a mode of consciousness-namely, consciousness of the self-and all consciousness is reflective, that is, it attends to objects which it represents over against itself; ${ }^{19}$ in this case, the self as subject represents itself as object, so that these two are not immediately identical. Our original self-acquaintance must instead consist in self-feeling (Selbstgefühl) because in feelings something is given to us, not reflectively grasped..$^{20}$ That which is given to my "self-feeling," Novalis adds, is being. It might seem that, since this feeling is precisely my Selbstgefühl, the unitary "being" that I feel is simply my own unitary self. ${ }^{21}$ Against this, Frank maintains that Novalis uses the notion of "self-feeling" to denote not the feeling of a pre-existing self but "the feeling of a dependence on being," "which is not at all graspable under the description I." ${ }^{22}$ Although selffeeling feels a unitary being and not a prior self, self-feeling nevertheless makes reflective self-consciousness possible and is, therefore, rightly called "selffeeling." Self-feeling makes self-consciousness possible because the subject-self can recognize the object-self to be identical with itself only if it feels that they have something in common. But since this common element must precede the subject/object division, it must be the undifferentiated unity of being. ${ }^{23}$

Having sketched the main features of Frank's interpretation, we can proceed to that of Beiser, according to which the Romantics believe that what Frank calls "being"- but what Beiser prefers to call "the absolute" — can be known. On Beiser's view, the Romantics conceive the absolute as a unitary, self-sufficient, substance which develops organically into the world's various finite subjects and objects, all existing as different stages in the absolute's self-realization. Because the absolute develops, it follows a plan and thus constitutes an intelligible and rational structure which pervades all that exists. So while Beiser agrees with Frank that there is a unitary, mind-independent, source of all reality, he differs from Frank in holding that this unitary source is rational and knowable (specifically, we can know it to be an intelligibly developing organism). However, Beiser makes two significant qualifications. First, he admits that he simplifies matters in saying that the Romantics take the absolute to exist independently of mind: for them, the absolute necessarily develops into mind, or subjectivity, as its fullest realization. ${ }^{24}$

${ }^{19}$ Schriften, II, I05, \#2; Fichte Studies, 5.

${ }^{20}$ Schriften, II, I I 3-I 4, \# I 5 ; Fichte Studies, I $2-13$.

${ }^{21}$ So argue Charles Larmore ("Hölderlin and Novalis," in The Cambridge Companion to German Idealism, ed. Karl Ameriks [Cambridge: Cambridge University Press, 2000], I 54) and Géza von Molnár (Novalis's "Fichte-Studies": The Foundations of his Aesthetics [Novalis's "Fichte-Studies"] [The Hague: Mouton, I970], 39). However, as Molnár himself shows, the absolute as unity cannot directly be the self; although Novalis sometimes calls it the self, this is only because he is considering it from the perspective of the self's endeavor to grasp the unity that lies at its own basis (Molnár, Novalis's "Fichte-Studies," 44).

${ }^{22}$ Frank, Selbstgefühl (Frankfurt: Suhrkamp, 2002), 34, 37.

${ }^{23}$ For this argument, see Frank, Philosophical Foundations, I07; and Frank, "Identity and Subjectivity," in Deconstructive Subjectivities, ed. Peter Dews and Simon Critchley (Albany, NY: SUNY Press, I996), I28-29.

${ }^{24}$ Beiser, German Idealism, 356 . 
It is more accurate, then, to say that the absolute exists prior to the subjects that manifest or realize it, although, because the absolute necessarily realizes itself as these subjects, it cannot exist independently of them. Second, Beiser contends that, for the Romantics the absolute-because it is a whole-cannot be known through discursive understanding (which is conceptual, predicative, and inferential), but only through an intuitive form of reason which is identical to aesthetic perception (taking the latter to be perception of wholes)..$^{25}$

To show that Novalis is committed to the idea that the absolute develops organically and intelligibly, Beiser focuses primarily on Novalis's most substantial philosophical text after the Fichte-Studies, the Allgemeine Brouillon. There Novalis insists on seeing nature as visible spirit and spirit as invisible nature: ${ }^{26}$ that is, both nature and spirit are levels of a single, self-organizing reality. Confirming that Novalis thinks that reality organizes itself in an intelligible way, the Brouillon also suggests that we can rationally intuit the organizing principles behind nature and scientific knowledge. ${ }^{27}$ In notable contrast to Beiser, Frank's reading of Novalis draws principally on the Fichte-Studies, and he dismisses the Brouillon as "genuinely fragmentary, in the bad sense" that it remained unfinished. ${ }^{28}$ Other scholars have agreed with Frank that the Brouillon represents a retrograde step for Novalis in virtue of its contention that the absolute develops intelligibly and can be known. ${ }^{29}$ In fairness, though, we must ask whether Novalis has any good philosophical reasons to move from construing being as unknowable to thinking that being can be known to be an organic, self-developing, whole.

I now want to argue that Novalis does have a good reason for this move: his earlier denial that we can know about the absolute conflicts with his concern to "re-enchant" nature, a concern which is present from the earliest stages of his thought. ${ }^{30}$ This conflict forces Novalis to revise his philosophical views. By re-examining Novalis's writings in relation to the theme of enchantment and disenchantment, then, we will be able to confirm that his philosophical position changes between the Fichte-Studies and the Allgemeine Brouillon. In particular, he increasingly comes to believe that being can be known to be an organic, self-developing, whole (and, further, that this whole can be known discursively, not only intuitively). However, the emphasis on the unknowability of being which Frank rightly identifies in Novalis's earlier work persists in his later works in a way that Beiser overlooks. For the later Novalis, the absolute develops in an irreducibly spontaneous way, and

${ }^{25}$ Beiser, Romantic Imperative, 62.

${ }^{26}$ Schriften, III, 252 , \#69.

${ }^{27}$ Schriften, III, 448, \#934.

${ }^{28}$ Frank, Unendliche Annäherung, 25.

${ }^{29}$ William Arctander O'Brien (Novalis: Signs of Revolution [Signs] [Durham: Duke University Press, I995], 204) accuses the Brouillon of harboring a "nostalgic desire for transcendent knowledge." See also Jacques Derrida, Dissemination, trans. Barbara Johnson (Chicago: University of Chicago Press, I98I), 50-53.

${ }^{3 \circ}$ For example, Novalis's early essay, On Inspiration (written between I 788 and I 790 ), claims that, in prehistoric times, "Oriental" people directly experienced nature as the embodiment of a divine being and as the inspiration for poetic language (Novalis, Schriften, II, 22-23). Suffusing the essay is a favorable contrast between this "enchanted" view of nature and the modern European experience of it. For discussion, see Kristin Pfefferkorn, Novalis: A Romantic's Theory of Language and Poetry (New Haven: Yale University Press, I988), 6I-62. 
therefore we cannot fully understand its development: necessarily, the absolute must remain partly incomprehensible to us.

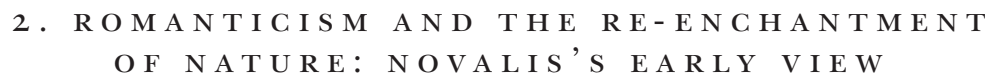

In this section, I will begin my reconstruction of Novalis's philosophical development by explaining in what sense he is concerned to "re-enchant" natural phenomena. Then, I will trace how this concern informs the epistemological and aesthetic views that he presents in his earlier work-that is, in his Fichte-Studies, as well as some of his notebooks dating from 1798.

Although, as I remarked above, the disenchantment of nature was always a source of concern, Novalis's most explicit statement of his unhappiness with this disenchantment is his late essay, Christendom or Europa (I799). Europa offers a schematic history of European civilization which unfavorably contrasts modern, enlightened, culture to an idealized version of the Catholic middle ages. Europa particularly laments the rise of mechanistic science, secularism, and the Enlightenment commitment to rational explanation. Embedded in this lament is Novalis's unhappiness that our "modern way of thinking" denies that nature is poetic, sacred, animate or mysterious. ${ }^{3 \mathrm{I}}$ This way of thinking, he adds, has "turned the infinite, creative music of the universe into the uniform clattering of a monstrous mill, driven by the stream of chance." Europa thus portrays the disenchantment of nature as a multi-faceted historical phenomenon, involving our loss of any sense that nature is divine, alive, and mysterious.

The elements of Europa's picture of disenchantment are already contained in earlier writings by Novalis, especially his notes on Goethe (late I798), but also his mixed fragment collections from mid-I798. He claims that the ancients were animists, who perceived souls (Seelen) and spirits (Geistern) in trees, landscapes, and stones. ${ }^{32}$ But, as civilization has progressed, we have abandoned the ancient belief that objects are inherently sacred. ${ }^{33}$ Indeed, "[t] he age has passed when the spirit of God was intelligible [verständlich]. The meaning [Sinn] of the world is lost." ${ }^{44}$ Based on these comments, we can see that, for Novalis, "disenchantment" has involved a three-fold intellectual shift whereby we have ceased to see natural phenomena as (I) having intrinsic meaning (Sinn or Bedeutung), (2) embodying spirit(s), and (3) being mysterious. Hence, Europa tells us, the characteristically modern view is that the earth is meaningless (unbedeutend) and that natural things are neither "incomprehensible" nor "deserving of wonder." 35 These three central dimensions of disenchantment are interwoven: if one takes natural things to embody spirits, then one will find these things meaningful, signifying or indicating the presence of spiritual beings. But these spiritual beings, Novalis assumes, are free-that is, they can initiate actions independently of any prior conditions. ${ }^{36}$ Consequently,

\footnotetext{
${ }^{3}$ Schriften, III, 5 I 5 ; Philosophical Writings, I 44.

${ }^{32}$ Schriften, II, 648, \#476; Philosophical Writings, I I 7.

${ }_{33}^{3}$ Schriften, II, 645, \#466; Philosophical Writings, I I 5.

${ }^{34}$ Schriften, II, 594, \#3 I 6; Philosophical Writings, 8 I

${ }^{35}$ Schriften, III, 5 I6, 508; Philosophical Writings, I3 8, I45.

${ }^{36} \mathrm{On}$ this definition of freedom, see Novalis, Schriften, II, 288, \#647; Fichte Studies, I 86.
} 
the actions of these spirits are not wholly predictable or explicable. The spirits' mystery and unpredictability carries over into the natural things that embody and manifest them; thus, when modern scientists treat natural things as exclusively material, they are simultaneously denying that these things are "strange." 37

Novalis objects to the disenchanted view of nature, at least in part, because it induces humanity to "scorn" natural things instead of responding to them with the wonder and respect they deserve..$^{3}$ Thus, he objects to disenchantment because its inevitable consequence is that we devalue nature. Novalis therefore tries to ascertain how our culture could be transformed so that we could again find natural things enchanted-meaningful, inspirited, and mysterious. This project implicitly informs his reflections in the Fichte-Studies, with the result that his rethinking of knowing as an "unending activity" (with which the text concludes) underpins a theory of romantic poetry according to which this kind of poetry re-enchants natural phenomena. We must reconsider, firstly, how the Fichte-Studies supports Novalis's theory of romantic poetry, and, secondly, how romantic poetry (on this theory) re-enchants natural things.

As we have seen, the Fichte-Studies argues that our awareness of depending on being drives us to try to know about being, but that each such attempt results only in knowledge of some particular, limited, phenomenon; as Pollen summarizes: "[e]verywhere we seek the unconditioned, and find only things." ${ }^{9}$ Sections 5 and 6 of the Fichte-Studies start to draw out how these epistemological claims bear on poetry. Novalis stresses that, whenever we attempt to know the absolute, we end up only imagining it. He refers to "the element of imagination [Einbildungskraft] $\ldots$ of the one and only absolute anticipated ... through the negation of everything absolute." ${ }^{\circ}$ More specifically, if we acknowledge (as we should) that our items of knowledge about finite things do not confer knowledge of the absolute, then, simultaneously, we begin to experience these finite things differently, as indications-or signs (Zeichen) - that the absolute remains unknown, lying beyond their finite sphere. When we thus experience perceptible items as signs of the absolute, we are imagining the absolute, because we are recasting the finite things that are given to us as images (Bilder) or indications of something other than themselves-namely, inaccessible being. ${ }^{4 \mathrm{~T}}$

The Fichte-Studies implies that, if we become rightly self-conscious of the endlessness of our quest to know being, then we will acquire a poetic experience of the phenomenal world as a realm of images, a "symbolic picture."42 Poetic activity, then, is any activity which brings about such experience of finite entities as images. Since philosophy, too, should become conscious of its status as "unending activ-

${ }^{37}$ Schriften, II, 646, \#468; Philosophical Writings, I I 6.

${ }^{38}$ Schriften, III, 508; Philosophical Writings, I 38 .

${ }^{39}$ Schriften, II, 4I 2, \#I; Philosophical Writings, 23.

${ }^{40}$ Schriften, II, 273, \#568; Fichte Studies, I7I.

${ }^{41}$ Earlier in the Fichte-Studies, Novalis had defined the imagination (following Kant) as the power to connect sensible materials to concepts of the understanding (Schriften, II, I69, \#2 I9; Fichte Studies, 67). Now, modifying this definition, he claims that the imagination presents the sensible as spiritual (as pointing to that which lies beyond it but cannot be sensed) while, reciprocally, presenting the spiritual as sensible (indicated by its finite image) (Schriften, II, 283, \#633; Fichte Studies, I 82).

${ }^{42}$ Schriften, II, 600, \#349; Philosophical Writings, 105. 
ity," it should become identical with poetic activity in this sense. Any poetic (or philosophical-poetic) productions which result from this activity are "romantic," according to Novalis's famous definition: "[b]y endowing the commonplace with a higher meaning, the ordinary with mysterious aspect, the known with the dignity of the unknown, the finite with the appearance of the infinite, I romanticize it." 43 He adds that " $[\mathrm{t}]$ he operation for the higher, unknown, mystical, infinite is the reverse-this undergoes a logarithmic change through this connection-It takes on an ordinary form of expression." That is, just as we come to experience ordinary things as images, simultaneously we imagine being or the absolute, and form an (avowedly inadequate) picture of it, through these ordinary things.

Novalis affirms the desirability of a romantic culture, in which poetic experience of the world would be widespread due to encouragement from romantic forms of philosophy, literature, art, religion, and even politics. He sees this culture as desirable partly because it would re-enchant nature, understood (as Novalis often does) simply as the totality of finite, material, knowable, objects. ${ }^{44}$ Each finite item within this totality can, in principle, be entirely understood, if one knows (I) its distinguishing features, and (2) the conditions that have sufficed for this object to be as it is. ${ }^{45}$ (Generally, Novalis takes 'understanding' [ Verstand] to be synonymous with 'discursive knowledge'.) The realm of finite phenomena, then, seems neither to hold any mystery for us nor to point to any "spirited" dimension beyond itself. If, however, we re-experience these finite phenomena poetically, as signs of the absolute, then they present themselves as both meaningful and mysterious, since they give indications of something which itself defies understanding-which, Novalis says, is unverständlich and mysterious (Geheimnißvoll) ${ }^{46}$ Moreover, on this poetic view, natural phenomena acquire an "inspirited" aspect. To see this, we must recognize that, for Novalis, my endeavor to know being is equally an endeavor to know what unifies me as a self-what makes my subject-self and object-self identical. Consequently, if I perceive natural phenomena to point to the absolute, then I equally perceive them as images of the (unknowable) unity of my own self. As Novalis says, one who could lift the veil of Isis-who could epistemically transcend the finite sphere-would uncover his or her self. ${ }^{47}$ From the poetic perspective, natural phenomena present themselves as embodying a reference to something spiritual-the unifying core of my (non-material, spiritual) self.

It might be objected that Novalis cannot simply associate romantic culture with re-enchantment, because, according to the second half of his definition of romanticism, the romantic depicts the absolute as mundane and finite. Therefore, we might suppose, romantic culture disenchants the absolute, picturing it in terms

${ }^{43}$ Schriften, II, 545, \#I05; Philosophical Writings, 60.

${ }^{44}$ For example, he writes that: "Everything that can become an object is, to that extent, nature" (Schriften, II, I66, \#205; Fichte Studies, 64). He contrasts nature, which is material, to the person (Schriften, II, I 58 , \# I 57 ; Fichte Studies, 56).

${ }^{45}$ When Novalis says that "[t] he sphere of the object [is] determination" (Schriften, II, I96, \#278; Fichte Studies, 94) - that objects are fully "determined"-he means that they are both (I) defined by the features differentiating them from other objects, and (2) as they are because of a chain of prior conditions.

${ }^{46}$ Schriften, II, 532, \#9; II, 268, \#5 56; Fichte Studies, I 66.

${ }^{47}$ Schriften, II, 584 , \#250. 
of finite items that are non-mysterious and materially perceptible. However, this operation of "logarithmizing" the absolute presupposes our acknowledgement that the finite things in terms of which we picture being are mere images and do not adequately represent it. Through this acknowledgement, we retain the insight that being itself is infinite and unknowable: "completely spiritual . . infinite . . . mysterious," as the Fichte-Studies says..$^{8}$ Romantic culture, then, would uphold an enchanted view of being alongside its re-enchantment of natural phenomena.

Novalis believes that we cannot return to the ancient view that divinities populate the world, but that, in a romantic culture, we could at least perceive natural things to be signs of the absolute and of the equally inaccessible unity of the self. This conception of romantic re-enchantment rests on the philosophical position which Frank identifies in Novalis, namely, the position that unitary being underlies all existents but that we cannot know about unitary being. Because the absolute exists, we can come to experience particular natural things as pointing to it; but, because the absolute is unknowable, we can experience these things only as indicating that the absolute lies beyond our ken. However, there is a crucial problem with Novalis's early conception of re-enchantment, I will now argue.

\section{PROBLEMS W I TH NOVALIS'S \\ C O N C EPT I O N OF R E- E N CHA N T M E N T}

The problem with Novalis's early conception is that it presupposes that we originally experience natural things as disenchanted (entirely material, conditioned, and fully intelligible), prior to reflecting on our cognitive limitations and coming to re-experience nature poetically. Given that we are conscious only of what we conceptually discriminate and judge, our original and basic experience is necessarily of a world of separate, mutually conditioning, knowable objects. ${ }^{49}$ Since the totality of these things is nature, our original mode of experience embodies an understanding of nature as merely the concatenation of conditioned material things. Although we can learn to perceive nature differently, as containing mysterious meaning, this is possible only because we first have knowledge of finite things, which we can, through self-reflection, come to recognize as insufficient for knowledge of the absolute. ${ }^{5 \circ}$

A number of fragments expose Novalis's presupposition that we originally find natural things disenchanted. In a fragment from early I 798 , he writes that

it is only spirit that poeticises objects and changes of material, and . . the beautiful ... cannot be found already present in phenomena ... All the sounds which nature produces are rough — and devoid of spirit—only the musical soul finds the rustling of the forest ... the babbling of the brook melodious and meaningful [bedeutsam].$^{51}$

${ }^{48}$ Schriften, II, 567-68, \# 556; Fichte Studies, I 66.

${ }^{49}$ One might think that surely, insofar as we feel being, we must be conscious of it and not only of finite things. But, for Novalis, consciousness is inherently cognitive, while feeling is non-cognitive, and hence is not strictly an instance of consciousness. Frank designates feeling "an ideal limiting case of consciousness" (Philosophical Foundations, I7I).

${ }^{50}$ As Hannah explains, "even though the subject's real-world experience is fixed in necessary ways, nothing prevents the subject from reformulating that experience in a poetic fashion" (Richard W. Hannah, The Fichtean Dynamic of Novalis's Poetics [Fichtean Dynamic] [Bern: Peter Lang, I98 I], 97).

${ }^{5}$ Schriften, II, 543-44, \#226; Philosophical Writings, 7 I. 
Painters, the passage continues, may appear merely to imitate natural phenomena, but really they "see actively," actively learning to find meaning in these initially meaningless phenomena. In the notes on Goethe, Novalis likens natural phenomena to relics from classical antiquity on the grounds that both are only "bod[ies] which first receive meaning through the eyes of spirit." $5_{2}$ And in a fragment from mid-I798, he maintains that we must actively "posit nature as incomplete, [in order] to reach an unknown variable" within it (namely, being). ${ }^{53}$ We do not originally find in natural phenomena any reference to being; we have to posit this reference, by striving to know being, and then reflecting that we have gained only finite knowledge.

Why should it be problematic that Novalis presupposes that we originally find natural phenomena meaningless? This is a problem because he aims to explain how our current, disenchanted, view of nature could be overcome. In part, through his idea that we can reinterpret natural phenomena as signs of being, he shows how we could overcome disenchantment. But partly, too, his position entails that even a romantic culture could never completely overcome disenchantment, since the disenchanted view of nature will necessarily remain basic to every individual, each of whom must learn, individually, to transform his or her own experience. Novalis's conception of romanticism, then, does not fully satisfy his goal of showing how disenchantment could be overcome, since according to his conception this overcoming depends upon disenchantment remaining present in the mode of experience original to each person.

My claim that Novalis presumes that we have an "original" understanding of nature may well be surprising in view of his anti-foundationalism, which states that we have no incorrigible principles or items of knowledge. Our originally disenchanted understanding of nature can be corrected, though, according to Novalis, if we start to re-experience finite things as images of being. Nonetheless, he presupposes that this disenchanted understanding is basic to all of us, and this sits uneasily with his anti-foundationalism. This tension arises because Novalis's anti-foundationalism is actually bound up, as we saw earlier, with his idea that we cannot know being, but can know only finite entities-an idea which implies that we necessarily understand nature to be disenchanted (to be the totality of finite, knowable, entities), prior to recasting our experience poetically. Novalis's view that our knowledge is confined to the realm of finite objects implies that a certain understanding of nature is basic to humanity, even though this implication stands in some tension with his anti-foundationalism. ${ }^{54}$

${ }^{52}$ Schriften, II, 640, \#445; Philosophical Writings, I I I-I 2.

${ }^{53}$ Schriften, II, 559, \#I 5 I; Philosophical Writings, 65.

${ }^{54}$ Another problem is that Novalis's history of civilization states that disenchantment has only become endemic in modernity; how, then, can it be basic to all humanity? Here Novalis argues that pre-modern cultures were more poetic and therefore encouraged people to romanticize their experience; because modernity is prosaic, it fails to do this and leaves people with their original mode of experience (Schriften, II, 533, \#33; Philosophical Writings, 27). A less tractable problem is that Novalis values those-especially children, including his late fiancée, Sophie-who spontaneously find the world enchanted, not yet having been corrupted by prosaic modern ways. This clearly suggests that disenchantment is not our original mode of experience at all, but must be learned. At this point, Novalis's epistemological views, with their implication that disenchantment is basic, again clash with his desire to think that disenchantment can be overcome (an overcoming of which he sees Sophie as a harbinger). See also note 82 . 
Novalis does not overtly acknowledge the problem with his early conception of re-enchantment, but over the course of $\mathrm{I} 798$ he revises his conception of the poetry/nature relation in ways that recognizably address this problem. In general, to solve this problem, he must adopt a revised epistemology, according to which we can (at least given appropriate cultural conditions) originally and directly find natural things meaningful and inspirited, without having to first transform an initially antithetical mode of experience. Novalis moves toward this solution with his much-maligned doctrine of "magical idealism" (magischer Idealismus), which features repeatedly in his various fragment collections from early to mid-I 798, and recurs at intervals in the Allgemeine Brouillon. According to his main formulations of the doctrine of magical idealism, we should learn to develop our control over our "external" senses, the senses through which we receive stimuli from the outer world. If we could control our outer senses fully, then we could perceive the outer world as we choose, unconstrained by external events. Someone with such self-control "will compel his senses to produce for him the shape he demands-and he will be able to live in his world." 55 Such a person would be a "magical idealist," so-called because "magic is the art of using the senses at will [willkürlich]" 56 to create impressions which depend for their existence upon only the self and not the external world.

Readers have often dismissed Novalis's magical idealism as fantastic, but we can appreciate that the doctrine does, at least, respond to the problem that affected his previous account of re-enchantment. ${ }^{57}$ One element of the doctrine is its injunction that we should free ourselves from being constrained to perceive those natural effects that would ordinarily follow when their conditions are given. For example, should I see a bird's egg break open, I should be able to see a dog emerge, or perhaps a human being or any other entity that I choose; the "natural world" would thus become "a wonder-world," Novalis writes..$^{8} \mathrm{He}$ also states that, in becoming "independent of the actual world of the senses," we would "become accustomed to the world of signs." " We would choose to perceive those effects which strike us as having incomprehensible significance, and so as pointing to the unity of being beyond the sphere of finite things. An important element of magical idealism, then, is its prescription that we should raise ourselves to a psycho-physical state in which our primary experience of the world is no longer that of a meaningless chain of conditions, but, rather, that of a directly significant and mysterious realm. With this doctrine, Novalis apparently succeeds in identifying a way in which we could fully overcome disenchantment: by transforming our basic mode of representation and the sensory functions with which it is entwined.

Unfortunately, there is a tension in Novalis's doctrine of magical. Although he claims that magical idealism (and the practices it recommends) provides a way to

${ }^{5}$ Schriften, III, $583, \# 247$.

${ }^{56}$ Schriften, II, 546, \#I09.

${ }^{57}$ In partial defense of magical idealism, Beiser and Neubauer argue that it also involves cultivating the outer senses to perceive meanings that nature antecedently contains. See Beiser, German Idealism, 425; and John Neubauer, Bifocal Vision: Novalis's Philosophy of Nature and Disease [Bifocal Vision] (Chapel Hill, NC: University of North Carolina Press, I97I), 63-67.

${ }^{58}$ Schriften, II, 548, \# I I 2.

${ }^{59}$ Schriften, II, 549-50, \# I I 7. 
overcome disenchantment completely, the doctrine actually presupposes a disenchanted understanding of nature as the totality of material bodies interacting in causally determined ways. In particular, the doctrine of magical idealism assumes that the sentient body is part of the world's nexus of conditions and determinations: "the body ... is dependent on external stimuli, whose essence we call nature or the external world." ${ }^{\circ}$ Our aim is to lift our outer senses clear of this nexus and bring them under the control of the mind. Now, Novalis does not merely believe that we originally experience our senses as determinate, conditioned items and that we must come to re-experience the senses poetically. ${ }^{6 \mathrm{I}}$ Rather, according to magical idealism, we become able to experience anything poetically only through our prior activity of gaining control of our outer senses (so that we can perceive just those events that we opt to perceive). But to gain control of the outer senses, we must control the body through concrete medical and psychological practices. Novalis assumes, then, that the self can freely choose to engage in physical practices which transform the body and (somehow) bring it, and the outer senses, under the self's control. Here Novalis presumes a contrast whereby subjectivity is uniquely free (the self chooses to engage in self-transforming practices, or it chooses what sensory impressions it wants to receive), while physical nature is completely determined. As Novalis says, "freedom is only thinkable in opposition to a world." ${ }^{62}$ This contrast is a problem not only because it creates a puzzle about how non-physical subjectivity can intervene into the physical sphere, but also because it means that magical idealism is predicated on the belief that nature is purely material, wholly conditioned, and intelligible. Even as magical idealism promises to show how we could definitively overcome disenchantment, the doctrine presupposes the truth of a disenchanted view of nature. So although magical idealism seemed to have the potential to resolve the problems with Novalis's previous account of re-enchantment, it actually deepens them. As a result, Novalis continues to need a genuinely improved account of re-enchantment. The next section will argue that the central tendency of his Allgemeine Brouillon is to develop such an account.

4. NOVALIS'S S C I E N T IFI G S T U D IES :

THE SELF-ORGA N I I N G NATURAL WORLD

Recall that Novalis's early program of "romanticization" presupposes that each of us originally finds nature disenchanted, and so this view still partly accepts the inescapability of disenchantment. He must overcome this problem by explaining how we could possibly start to find nature directly mysterious and meaningful. The explanation he reaches is that every natural phenomenon refers, meaningfully, to an infinite range of similarly structured phenomena, so that the quality

${ }^{60}$ Schriften, II, 546, \# I I I; Philosophical Writings, 6I.

${ }^{6}$ Fichtean interpreters of Novalis maintain that he does advocate changing only how we experience our senses, which only ever appear to receive outer stimuli due to the ego's ignorance of its prior positing of the non-ego. See, for example, Hannah, Fichtean Dynamic, 29. Such Fichtean readings should be rejected: as I argued in section I, Novalis actually criticizes Fichte by re-emphasizing the self's dependence on being, a dependence which he thinks is reflected in our sensory and felt responsiveness to what is given (Schriften, II, I I 3-I 4, \# I 5 ; Fichte Studies, I 3 ).

${ }^{62}$ Schriften, II, 288, \#647; Fichte Studies, I 86. 
of meaningfulness really exists in natural things, prior to our experience of them. Science can make us aware of this quality, whereupon we will directly find natural things enchanted. These positions materialize in the Allgemeine Brouillon.

The Brouillon comprises a series of notes towards what Novalis calls an "encyclopedistic" of the sciences: a preliminary plan of the relations between the different sciences, providing the basis on which a full encyclopedia could be constructed. ${ }^{63}$ The Brouillon draws on the extensive scientific studies which Novalis conducted at Freiberg from the summer of 1798 to the spring of 1799 . These studies convinced Novalis that there are series of correspondences between the processes with which the various sciences deal. Specifically, he became convinced (I) that every science primarily studies relations, processes, and interactions, since individual entities of all kinds are as they are only because of their multiple relations to other things; ${ }^{64}$ and (2) that correspondences-"relations-similarities-identities"-obtain between these diverse processes and entities. ${ }^{65}$ For instance, he says that youth corresponds to fluidity, age to rigidity; that women correspond to oxygen, men to flame; and that sensing recapitulates the process of devouring food at a higher, more psychical, level. ${ }^{66}$ Correspondences also obtain between the principles of the different sciences, since their objects of study correspond. In virtue of their manifold correspondences, natural processes and phenomena are intrinsically meaningful, each one pointing to an infinite variety of similarly structured processes. Novalis therefore refers to the "mutual representation of the universe" and states that "the universe also speaks." ${ }^{67}$ Previously, he had thought that the conditioning of every natural phenomenon by its relations to all the others makes nature (in principle) meaningless. Now, based on his deeper acquaintance with scientific accounts of these relations, he concludes that they inscribe meaningful references in the internal structures of each natural thing.

At this point, Novalis finds himself obliged to provide an explanation for the prima facie surprising level of interrelation and systematic integration which he has discerned among the various processes of nature. He says, for example, that "[e]very phenomenon is a limb in an immeasurable chain-which comprehends all phenomena as limbs. The theory of nature must become ... (a continuum) a history-an organic growth." ${ }^{\prime 8}$ That is, he thinks that the interrelations within nature would not obtain so systematically (embracing all phenomena as "limbs") unless these interrelations derived from some self-organizing, growing, agency. In order to conceptualize this organizing activity, Novalis draws on some implications

${ }^{63}$ On the Brouillon, see also Theodor Haering, Novalis als Philosoph (Stuttgart: Kohlhammer, I954), ch. I3; Neubauer, Novalis (Boston: Twayne, I980), ch. 3; and Herbert Uerlings, ed., Novalis und die Wissenschaften (Tübingen: Niemeyer, I997). In "Novalis und die Wissenschaften: Forschungsstand und Perspektiven" (in Novalis und die Wissenschaften, I-22), Uerlings construes the Brouillon consistently with Novalis's earlier work, as striving for, but never reaching, knowledge of nature as a whole (I I-I 2). Against Uerlings, I take the Brouillon's incompleteness and fragmentation to reflect Novalis's new convictions that we can have knowledge of nature as a whole, but that this is limited in practice and in principle, because of nature's spontaneity.

${ }^{64}$ Schriften, III, 254, \#79; III, 26I, \#I I3.

${ }_{5}^{65}$ Schriften, III, 280, \#233.

${ }^{66}$ Schriften, III, 258, \#97; III, 262, \# I I 7; III, 288-89, \#273.

${ }^{67}$ Schriften, III, 246, \#I 37; III, 267-68, \#I 43; Philosophical Writings, I 25.

${ }^{68}$ Schriften, III, 574, \#I 40. 
of his idea of unitary being-implications that he had hitherto left unexplored. These implications surface on occasions in the Fichte-Studies when he equates unitary being with nature. He has strong philosophical reasons for doing this. Ultimately, neither finite selves nor finite objects can differ from being, otherwise being would not be entirely unitary. Being must, therefore, create differentiation within itself, structuring itself into different finite subjects and different finite objects. ${ }^{69}$ That being gives itself this complex articulation means that it operates in the manner of a self-structuring organism. To Novalis, then, it makes sense to equate being with a kind of large-scale organism, or with nature considered as a whole, self-organizing, system.

Novalis introduces this connotation of nature in the Fichte-Studies in a note that lists nature's four meanings: (I) the essence of a thing; (2) "all things as such"- the totality of finite objects; (3) "[e]verything that is not-person"- the totality of specifically non-human objects; (4) "the state of a thing that comes into being for its own sake without subjective causality." 70 That is, by (4), anything is natural that emerges or develops spontaneously without being artificially produced by human agents. By (4), then, something is natural when it is self-forming and self-producing-in sum, organic (so that even inanimate natural things must somehow be derivative approximations to the organic). But since nature-in sense (2), the totality of finite things-itself exists spontaneously, not as an effect of human production, nature is itself natural-self-producing — and so must be viewed as one large-scale organism, within which all entities are interrelated as members. As this large-scale organism, nature can be equated with self-organizing being - as Novalis does at one point in the Fichte-Studies, referring to "the pure concept of nature" which "remains after all abstraction of form" ${ }^{\top 1}$ - a nature which, like being, is a unity underlying all differentiated forms. This absolutely unitary being/nature-"the whole nature" as Novalis calls it, ${ }^{72}$ (hereafter, "Nature")—is irreducible to the totality of finite material objects-Novalis's "actual nature" (hereafter, "nature"). Rather, unitary Nature precedes, and structures itself into, this totality.

In the Brouillon, Novalis draws out this implication that being is organic Nature, investigating how the absolute structures itself into the myriad levels of nature, as well as the many subjects who observe and conceptualize the processes occurring at each level. ${ }^{73}$ "One can rightly call the complete system of nature a complete individual," namely, the "world-structure-world-organism." 74 The Brouillon sketches a complex account of the universe as an organism. On this account, at

${ }^{69}$ As Frank writes, the Romantics could not have "a philosophy of absolute identity, if its absolute did not contain within itself that which it is not: relativity, the difference of separate essential tendencies. .. . The structure of the absolute is thus connected with that of the organism" and of "nature as a thoroughly organized being" (Frank, Philosophical Foundations, I23, I22).

${ }^{70}$ Schriften, II, I87, \#247; Fichte Studies, 85.

${ }^{71}$ Schriften, II, I 58 , \# I 56 ; Fichte Studies, 56.

${ }^{72}$ Schriften, III, 4I 9 , \#776.

${ }^{73}$ Perhaps Novalis left this implication undeveloped in the Fichte-Studies because it amounts to a claim to know about being (in its self-structuration, self-organization, etc.) - a claim which conflicts with his earlier denial that being can be known. (Beiser notes some other points in the Fichte-Studies where Novalis breaches his own strictures and ventures some knowledge-claims about the absolute; see Beiser, German Idealism, 4 I 6-I 7.)

${ }^{74}$ Schriften, III, 334, \#460; III, 352 , \#503. 
every level in nature we detect organized systems of organized processes, and the interlocking of these organized systems derives from the activity of the whole in organizing itself.

Each individual life-process is determined by the universal life-process, the natural system of an individual is determined both by the other individual natural systems and by the higher, universal system-ultimately by the natural system of the universe, insofar as this equally determines both of the former. (Novalis, Schriften, III, 334, \#460)

As that which organizes all of nature, this whole system is also the "world-soul" ("[t] he world is the macroanthropos ... there is a world-soul"), for the soul, according to Novalis, just is the form of organization of a material body or, in this case, of the material world. ${ }^{75}$ It follows that, since all natural processes and phenomena exhibit at least some level of organization, they too have souls, and are microcosms of the world-soul.

Do natural processes and things embody not only life and soul but also spirit? Novalis vacillates over this, saying sometimes that spirit is the highest level of organization of a body and is found only in humans. Spirit is unique to humans because we are inherently disunified (containing various conflicting psychical elements) and we produce unified personalities in ourselves artificially, through conscious activity. ${ }^{76}$ This makes human organization the highest because it knits together the greatest amount of diversity. However, Novalis claims that the organization of natural processes is never complete either; rather, these processes constantly strive to make themselves more completely formed and organized. Consequently, he sometimes - and most consistently_says that all natural processes and phenomena have "spirit" too: they strain to render themselves more completely organized (a striving which must manifest an activity of the world-soul within them, endeavoring to articulate itself more tightly). Each natural phenomenon embodies spirit, understood as the striving for organization, and so each is a "You. (Instead of non-self-You.)": each is another self, as is each human being. ${ }^{77}$ The spirit within human individuals is only a higher manifestation of the same kind of spirit which is contained in every natural thing-higher presumably because it results from humans' distinctively conscious pursuit of unification.

Novalis maintains that, because the whole organizes itself, it is self-determining: it gives itself determinate structure, and it does this freely: "Life is freedom of nature. ${ }^{78} \mathrm{He}$ offers no single, definitive explanation of what he means by "freedom." Rather, two different understandings of freedom operate in different places in his work. The first dates from the Fichte-Studies, in which-discussing the contrast between determinate objects (Gegenstände) and their indeterminate "op-

${ }^{75}$ Schriften, III, 3 I6, \#407; Philosophical Writings, I28. Neubauer (Bifocal Vision, 44) argues that Novalis located the world's soul not inside the world (as Schelling did) but outside it, as God. However, O'Brien (Signs, I 58-59, 2 I6-26) convincingly argues that Novalis regards religious propositions as not literally true but merely partial, figurative, perspectives on the absolute. Consequently, Novalis conceives the absolute in non-religious terms, including, in the Brouillon, as a systematizing, organizing, force.

${ }^{76}$ Schriften, III, 250-5 I, \#63; III, 253 , \#76.

${ }_{77}$ Schriften, III, 430, \#820; Philosophical Writings, I 35 .

${ }^{78}$ Schriften, III, 27I, \#I 72. 
posite" (Gegensatz), namely, being-Novalis states: "The opposite of all determination is freedom. The absolute opposite is freedom." 79 On this view, freedom consists in the absence of determination; hence, the absolute's self-organizing activity is free because it is the source of all determinacy, and therefore no determinations pre-exist it to condition it. Unlike any activities of finite, conditioned processes, the activity of the absolute is wholly without ground and, in this sense, purely spontaneous. On the other hand, Novalis understands the whole's self-organizing activity to be free because the whole develops unconstrained by any exterior pressures, following its own plan: "nature [is] at once independent and self-modifying." ${ }^{\circ \circ}$ Nature exercises organic force, manifesting itself in various processes and drawing them into relations. Here Nature is not following any particular, finite, plan but just developing as any organism, qua organic, must: differentiating itself into determinate entities occupying definite relations to one another. Novalis's two understandings of Nature's freedom seem opposed. If Nature must unfold in the way characteristic of anything organic as such, then how can it consistently be held that the absolute develops wholly spontaneously, that is, that there is no explanation at all for why it develops as it does? Yet Novalis thinks that these two types of freedom can co-exist: he says in his notes on physics (late I799) that Nature both follows laws-that is, develops according to regular and predictable (organic) patterns-and acts from spontaneous "will" (Wille). ${ }^{8 \mathrm{I}}$ This co-existence is possible if Nature exerts spontaneity with respect to the particular sets of things, processes, and relations into which it organically arranges itself. Supporting this, Novalis adds that Nature both has "no will"-it must develop organically-and has "a particular will"-it exerts will or spontaneity in developing into particular things and processes and not others.

How does Novalis's emergent account of self-organizing Nature improve on his earlier conception of romantic re-enchantment? He now claims that, through their interconnections, finite natural things are meaningful and "inspirited" prior to our experience of them. It is, therefore, possible that we can directly experience natural things as meaningful and inspirited, as long as science first makes us aware of these qualities within nature. ${ }^{82}$ Moreover, since each natural thing refers to an infinite number of related things and processes, we can never exhaustively decipher its meaning, and so, if we come to recognize that natural things are meaningful, then we will directly find them mysterious as well. Plainly, Novalis now allocates to science a central role in restoring a culture of enchantment. But this science, he emphasizes, must not be the traditional, mechanistic science which "cleans[ed] the earth ... of poetry." ${ }^{83}$ Rather, the science in question must be poetic, precisely because it discloses myriad interrelations within nature. Fortunately, science is actually becoming increasingly poetic, Novalis contends: he has in mind such then-

${ }^{79}$ Schriften, II, 202, \#284; Fichte Studies, 99.

${ }^{80}$ Schriften, III, 247, \#50; Philosophical Writings, I 22.

${ }^{8}$ Schriften, III, 60I, \#29I; Philosophical Writings, I 57.

${ }^{82}$ Moreover, since Novalis thinks that meaning and spirit are antecedently present in nature, he can now say consistently that some (such as Sophie, see note 54) might be able to perceive these qualities without needing scientific education.

${ }^{8}$ Schriften, III, 5 I6; Philosophical Writings, I 44. 
burgeoning fields as chemistry, geology, and mineralogy, whose complex systems for classifying different substances were (he thought) revealing unexpected and infinite series of relationships between these substances. ${ }^{84}$

To explain how we can overcome disenchantment, Novalis has had to affirm that qualities of meaning and spirit are intrinsic to nature. But, to explain how natural things enter into the complex organization that gives them these qualities, he must in turn appeal to the idea that unitary being is all-encompassing Nature, arranging itself into the system of natural processes. With this, Novalis has become obliged to claim knowledge about the absolute: specifically, knowledge that the absolute structures itself organically, following certain characteristically organic, intelligible patterns of development. This seems to contradict his earlier contention that being is unknowable. Moreover, he apparently presents his knowledge about the absolute in a series of inferentially related propositions-including those that I have excerpted from the Brouillon. So, does Novalis now take discursive knowledge about the absolute to be possible? In the final section, I will argue that he does indeed think that the general pattern of Nature's development can be known-discursively—but that, because Nature exercises spontaneity in pursuing particular courses of development, we can never understand or explain why it assumes the particular forms that it does.

\section{THE KNOWABLE AN D THE UN KNOWABLE IN NATURE}

The Brouillon makes a range of seemingly incompatible claims regarding whether the absolute can be known. Sometimes, Novalis reiterates that we can gain knowledge only of finite things, which falls short of knowledge of "Nature [which] is per se inconceivable. ${ }^{85}$ Elsewhere, though, he claims that the absolute must somehow be seen as both unknowable and knowable: "[t] he universe is the absolute subject . .. In this its immeasurable [ unermeßlich] and at the same time measurable organization is already contained." ${ }^{86}$ How Nature organizes itself can be both measured and known, and also defies measurement and cannot be known. One reading of this latter passage readily suggests itself when we also consider Novalis's claim that "we can hope to explain it [i.e., the 'highest substance'] through the complete working-out of all the single physical limbs." ${ }^{\prime 7}$ Together, these claims appear to suggest that the world's organization is in principle completely intelligible, and that our knowledge of it would be completed were we to gain exhaustive understanding of all the processes in which the absolute manifests itself. But (so this suggestion runs) since there are too many such manifestations for anyone to exhaustively understand them all, in practice the organization of the absolute can be only partially, not completely, deciphered.

${ }^{84}$ Novalis stresses scientists' central preoccupation with classification (Schriften, III, 256, \#87; III, 363, \#559) - a preoccupation through which, Europa tells us, scientists have become "the first who [have] once more recognized and heralded the sacredness of nature" (Schriften, III, 520; Philosophical Writings, I48).

${ }^{85}$ Schriften, III, 302, \#342.

${ }^{86}$ Schriften, III, 38 I, \#633; Philosophical Writings, I 30.

${ }^{87}$ Schriften, III, 37 I, \# 596 . 
Actually, though, Novalis thinks that there are not only practical, but also stronger, principled limits on how far we can know about Nature and its self-organization. In principle, we can never know why Nature organizes itself into just these processes and phenomena, because there is no explanatory ground of this fact. That Nature manifests itself in these particular phenomena is the effect of Nature's sheer spontaneity. Qua spontaneous, Nature is not rationally intelligible, for its spontaneous activity is devoid of any ground at all. Novalis muses: "Has nature always followed laws ... ?"88 Yet he had already concluded that Nature is both law- (or rule-) governed and free of law-in that latter respect being unintelligible and a source of wonder:

Connection of the wonder- and natural world.... Wonder- and natural world are ... one. (Rule and non-rule.) Non-rule is ... arbitrary rule (Willkürregel) —chance-wonder-rule. Rule—direct law-indirect, $\left(\right.$ crooked) rule $=$ unrule. ${ }^{\prime 99}$

From Novalis's perspective, we can know that Nature develops organically and regularly, and that, as a result, all particular phenomena and processes are interrelated, incorporating references to one another and exhibiting internal organization. But we cannot know, for example, why just these chemical substances are the ones that exist and why they combine in these specific ways-although we can know that these substances must, in general, exhibit complex interrelations and be capable of combining and interacting. Nature's organization is partly knowable (at least in principle), in respect of its generally organic, interrelational structure, but partly unknowable, in respect of the spontaneity which guides Nature into specific forms of organization. Novalis, therefore, insists that all items or fields of knowledge are simultaneously "non-knowledges," and that "[w] hoever produces a science, must also ... produce a non-science-whoever knows how to make something comprehensible, must also know how to make it incomprehensible-The teacher must be able to produce knowledge and ignorance." $9 \circ$ Our ignorance stems not merely from our practical inability to exhaustively decipher Nature's organization, but also from the fact that this organization is shot through with unfathomable spontaneity. Moreover, since each particular phenomenon is a microcosm of Nature as a whole, each phenomenon must contain some spontaneity such that no amount of study can afford us complete knowledge of it. Hence, Novalis maintains, "Nature is a whole-in which each part in itself can never be wholly understood." 9 г

The idea that we cannot know about Nature's spontaneity, nor understand Nature's organization insofar as it issues from and reflects this spontaneity, may seem self-undermining. Does Novalis not claim, precisely, to know that Nature has (in part) the character of spontaneity and that this spontaneity consists in activity that is groundless? However, to say that Nature is spontaneous is to mark only that there is an aspect of Nature's self-organizing activity about which we cannot know, because it just is not rationally intelligible. By marking the existence of this aspect, we do not thereby achieve positive knowledge about it; rather, we know

\footnotetext{
${ }^{88}$ Schriften, III, 430, \#827.

${ }^{89}$ Schriften, III, 409, \#730.

${ }^{90}$ Schriften, III, 375-76, \#6 I 2

${ }^{91}$ Schriften, III, 603, \#302; Philosophical Writings, I 57.
} 
that our knowledge of Nature and our understanding of its organization reach their limits at this point.

Further evidence that Novalis holds that Nature is in principle only partly knowable comes from his unfinished novella, The Novices at Saïs [Saïs], largely written in I798. In this work, a succession of individuals outline their perspectives upon nature or expound others' perspectives: the views considered include scientific and poetic views, mythic and early metaphysical views that nature is composed of the elements, and Fichte's view that nature is the not-self in need of overcoming. Some interlocutors even present aspects of Novalis's own (mature) view of nature: for one speaker, nature has its own spirit—or, "what is the same thing," it is "a single whole . . bound together in a history." ${ }^{22}$ Another speaker adds that each natural thing is a "unique You." ${ }^{93}$ The implication of this miscellany of claims is that no single claim or perspective exhausts or adequately captures the reality of Nature. As O'Brien observes, "The composition of Saïs out of so many discontinuous narratives stresses the insufficiency of each: there is no single truth, and no privileged discourse, about nature." 94

Following Beiser's interpretive lead, one might argue that Saïs only asserts the inadequacy to Nature of discursive knowledge-claims, while showing that there is an aesthetic mode of knowledge which is more adequate to Nature. According to this argument, our reading about the multiplicity of human perspectives on nature gives us an aesthetic intuition of Nature as the source of this multiplicity, and as the whole ramifying into the infinite multiplicity of finite phenomena and perspectives. Indeed, one of Saïs's closing speeches comes from a youth who articulates just this insight into the multiplicity and creativity of Nature- "its infinite variety, its inexhaustible joy" and its "fluidity" with which "only poets should deal."95 Yet the very existence of this speech implies that the content of our aesthetic insight into creative Nature can be restated propositionally. Thus, even if Saïs suggests that we can have aesthetic knowledge of Nature, the text simultaneously suggests that this knowledge can be rearticulated propositionally and that Nature is discursively knowable. Then again, Saïs's broader thrust seems to cancel out this latter suggestion, by implying that even those propositions (by the youth) which articulate Novalis's own conception of self-organizing, generative Nature are as inadequate to the infinity of Nature as are all the other proposed views. In short, just as the epistemological pronouncements made in the Brouillon initially appeared inconsistent, so Saïs, too, seems to contradict itself, implying partly that Nature can be known only aesthetically, partly that it can also be known discursively, and partly that it cannot be known at all.

We can straightforwardly resolve this apparent contradiction within Saïs by supposing that Novalis takes Nature to be both unknowable in certain respects and knowable (both aesthetically and discursively) in others. Confirming this supposition, the text ends with a speech by the "teacher," who states that one can only 85 .

${ }_{92}^{2}$ Schriften, I, 99; The Novices of Saïs [Novices], trans. Ralph Manheim (New York: Valentin, I949),

${ }^{93}$ Schriften, I, I00; Novices, 89 .

${ }_{94}$ O'Brien, Signs, 207.

${ }^{95}$ Schriften, I, I05; Novices 107, I08. 
"learn nature's secrets [through a] ... system based on experiment, analysis, and comparison" if one also learns to "speak of nature with worship and faith" and to maintain a feeling of "yearning" for Nature. ${ }^{96}$ To uncover Nature's secrets is to learn, as Novalis has in the Brouillon, that Nature has certain basic characteristics: it is unified, self-organizing, organic, developing, and spontaneous. (This learning may arise through the rearticulation of originally aesthetic, intuitive, insights.) Yet, in knowing-discursively—that Nature's characteristics include spontaneity, one knows also that one cannot know how or why Nature assumes the particular organization that it does. Because Nature thus remains partly unknowable, anyone who truly knows its basic characteristics must equally retain a "yearning" to know Nature more fully, as the teacher states.

Let me review my reading of Novalis's intellectual trajectory and clarify how it bears on the interpretation of Early German Romanticism more broadly. In his Fichte-Studies and earlier fragments, Novalis believes that the unitary being underlying the finite objects of our consciousness cannot be known. This belief supports his idea that romantic poetry re-enchants natural things by portraying them as ciphers of unknowable being - an idea which attracts Novalis because he wants to see how we could overcome the disenchanted experience of nature which prevails today. Yet, because his idea of romantic re-enchantment presupposes that we originally_pre-poetically_find natural things disenchanted, this idea also implies, troublingly, that we can never wholly escape disenchantment. Novalis, therefore, adopts the revised view that, in a poetically-scientific culture, we could appreciate the meaningful correspondences and spiritual agency within natural things, both characteristics being antecedently present in natural things for us to experience directly. In turn, he explains that the organization and agency in natural things derive from the spontaneous self-organization of being as Nature.

My interpretation bears out that of Beiser insofar as it shows, firstly, that Novalis increasingly comes to understand the absolute as a self-organizing whole, and, secondly, that this is his strongest understanding of the absolute (strongest because it allows the possibility of fully overcoming disenchantment). However, against Beiser, I have argued that both the Brouillon and Saïs suggest that reality's basic characteristics and general mode of development can be known discursively as well as aesthetically. Moreover, Frank's emphasis on the unknowability of being remains worthwhile, not only because it accurately characterizes Novalis's earlier writings, but also because it highlights that even the mature Novalis takes our discursive knowledge of being/Nature to be necessarily limited by Nature's spontaneity. Re-reading Novalis through the theme of disenchantment has thus enabled us to combine the true elements from both Beiser's and Frank's interpretations.

Moreover, through his idea that Nature unites organic intelligibility with unintelligible spontaneity, Novalis revalues Nature (and the natural phenomena which manifest it) both for being rationally purposeful and for being mysterious and incomprehensible. One might protest that Novalis has not elaborated a comprehensive account of precisely how Nature's organic intelligibility and unintelligible spontaneity interweave, or of exactly what natural phenomena, as the products of

${ }^{96}$ Schriften, I, I07-09; Novices I I 7-2 I. 
this interweaving, are like. That Novalis gave no such account is unsurprising: he was not a professional philosopher and his thought remains fragmentary. Nonetheless, I hope to have shown that he opens up a worthwhile direction for thinking about being and nature-worthwhile, above all, because it resituates his early insight into the unknowability of being within a broader, scientifically informed picture of the complex organization of the natural world. ${ }^{97}$

${ }^{97}$ For their helpful comments on the previous version of this paper, I thank the anonymous referees for the Journal. I also thank those who responded to an earlier draft presented at the University of Sussex Philosophy Society, and Garrath Williams for some help with translation. 